Vera Lucia Spacil

Raddatz

Doutora em Comunicação pela Universidade Federal do Rio Grande do Sul

Docente do Programa de Pós Graduação em Direito - Mestrado em Direitos Humanos - e do Curso de Jornalismo, da UNIJUI.

\section{Lara Nasi}

Doutoranda em Comunicação pela Universidade Federal de Santa Maria

Docente no curso de Jornalismo da Universidade Regional do Noroeste do Rio Grande do Sul.

\author{
Jornalismo como \\ campo mediador \\ dos Direitos Humanos \\ Journalism as mediator \\ field of Human Rights
}

Periodismo como campo mediador de los Derechos Humanos 


\section{RESUMO}

O campo midiático exerce um lugar estratégico na configuração das sociedades contemporâneas, contribuindo para a reflexão sobre o exercício da cidadania e da democracia. Este texto discute como as narrativas jornalísticas operam na construção de uma visão sobre os direitos humanos. Analisa reportagens publicadas pela Folha de S. Paulo (impresso) e Jornal do Brasil (on-line) no período de agosto de 2014 a março de 2015, a partir das palavras-chave: direitos humanos, democracia, liberdade de expressão, cidadania e direito à informação. Apoiando-se no pensamento de Motta (2013), Resende (201 1), Tuchman (1983), Gentilli (2005) e Bobbio (1986), apresenta as narrativas jornalísticas como o lugar onde ocorrem as mediações sociais, partindo da compreensão de que o jornalismo é um dos elementos para a constituição da realidade como fenômeno social compartilhado. A análise aponta que os direitos humanos são abordados de maneira episódica pelos jornais, a partir de pautas que emergem como fatos que o jornalismo se propõe a narrar, geralmente sem aprofundar ou contextualizar a temática.

Palavras-chave: Direitos Humanos; Direito à informação; Jornalismo; Narrativa; Cidadania.

\section{ABSTRACT}

The media field plays a strategic role in the configuration of contemporary societies, contributing to the reflection about the exercise of citizenship and democracy. This article discusses how the journalistic narratives operate in building a vision of human rights. It analyzes reports published by Folha de S. Paulo (printed edition) and Jornal do Brasil (on-line) from August 2014 to March 2015, from keywords: human rights, democracy, freedom of speech, citizenship and right to information. Relying on the ideas of Motta (2013), Resende (2011), Tuchman (1983), Gentilli (2005), and Bobbio (1986), it presents the journalistic narratives as the place where there are social mediations, based on the understanding that journalism is one of the elements for the constitution of reality as a shared social phenomenon. The analysis points out that human rights are approached episodically by newspapers, based on guidelines that emerge as facts that journalism proposes to narrate, generally without deepening or contextualizing the theme.

Keywords: Human Rights; Right to information; Journalism; Narrative; Citizenship.

\section{RESUMEN}

El campo de los medios de comunicación desempeña un papel estratégico en la configuración de las sociedades contemporáneas, lo que contribuye a la reflexión sobre el ejercicio de la ciudadanía y la democracia. Este artículo describe cómo los relatos periodísticos operan en la construcción de una visión de los derechos humanos. Analiza los informes publicados por Folha de S. Paulo y Jornal do Brasil (on line) desde agosto 2014 hasta marzo 2015, a partir de las palabras clave: los derechos humanos, la democracia, la libertad de expresión, la ciudadanía y el derecho a la información. Basándose en el pensamiento de Motta (2013), Resende (2011), Tuchman (1983), Gentilli (2005) y Bobbio (1986), tiene las narrativas periodísticas, como el lugar donde se encuentran las mediaciones sociales, basado en el entendimiento de que el periodismo es uno de los elementos para la constitución de la realidad como un fenómeno social compartido. El análisis apunta que los derechos humanos son abordados de manera episódica por los periódicos, a partir de pautas que emergen como hechos que el periodismo se propone narrar, generalmente sin profundizar o contextualizar la temática.

Palabras clave: Derechos Humanos; Derecho a la información; El periodismo; Narrativa; Ciudadanía.

Submissão: 17-8-2016

Decisão editorial: 1-08-2017 


\section{Introdução}

O mundo atravessa um momento crucial, no que diz respeito aos direitos humanos, como pontua $\mathrm{Ca}$ mila Baraldi(2014). Especialmente aguda é a situação dos países europeus diante do dilema e da pressão para receber, com dignidade, milhares de refugiados, os quais estão chegando também à América Latina, provocando um movimento de reflexão focado nos direitos humanos. E o jornalismo é elemento preponderante na difusão da informação, já que a mídia, na perspectiva de Luiz Gonzaga Motta (2013) contribui para a construção da realidade social, a partir das narrativas jornalísticas.

Além do jornalismo profissional, pode-se notar, ainda, outras incontáveis narrativas dos cidadãos da era digital, com seus dispositivos móveis de comunicação. E hoje, são milhões em todo o globo, produzindo algum tipo de informação ou conteúdo.Vivemos, portanto, a era da informação mobile que acelera os fluxos e os formatos de distribuição de conteúdos.

Um elemento diferencial da sociedade digital é a informação gerada pela conexão e distribuída via mobile. A tecnologia de mobilidade conectada à internet propicia que os sujeitos registrem, por si mesmos e sem filtros jornalísticos, os lugares, as coisas e os fatos vivenciados por eles. Esse cidadão passa a ser 
também um produtor de informação e não apenas um receptor, o que lhe confere autonomia do ponto de vista da democracia da comunicação. Conforme Vera Raddatz (2014) ao utilizar-se do direito à comunicação sem qualquer interferência de um órgão regulador, o cidadão pode difundir imagens e vozes que, de outra maneira, talvez não chegariam ao conhecimento do público. Dessa forma, a distribuição da informação passa a ser sinuosa - não horizontal nem vertical - porque se dá alinhada ao movimento produzido pelos cidadãos nos lugares em que estão.

Considerando o cenário em questão, este texto discute como as narrativas jornalísticas operam na construção de uma visão sobre os direitos humanos. Para isso, analisa-se a cobertura sobre o assunto nos jornais Folha de S. Paulo (impresso) e Jornal do Brasil (on-line), no período compreendido entre agosto de 2014 e março de 2015. A pesquisa, a partir de palavras-chave, aponta o que os referidos jornais destacam ao abordar o tema dos direitos humanos em suas narrativas.

1. Direitos Humanos e Jornalismo: o cenário da informação

A Sociedade da Informação, para Cicilia Peruzzo (2002) caracteriza-se como o lugar onde as relações transitam ou são mediadas pelas mídias Pressupõe um estado de direito a essa informação, vinculado ao exercício da cidadania e à vivência da democracia. Desse ponto de vista, os meios de comunicação exercem um papel essencial de acesso e visibilidade dessa informação. Na última década do século XX, uma nova grande mudança chega com as redes cibernéticas que vêm revolucionar todo o status quo 
conhecido até então, da economia às comunicações, passando a configurar uma realidade que passou a ser chamada de sociedade da informação, ou a era da informação (PERUZZO, 2002, p. 45).

Compreende-se assim essa noção dentro de uma perspectiva do que Norberto Bobbio (1986, p. 83-84) chama de "a democracia do poder visível" ou "a sociedade dos cidadãos". Nesta sociedade os direitos civis, políticos e sociais sofrem uma ampliação ou alargamento, como se fossem tecidos naturalmente pela força ou poder instituído naturalmente pela democracia, entendendo as questões públicas como de direito do público, ou seja, não sendo privadas não são também secretas.

O direito à comunicação não parece ser tangível, embora haja uma clareza na sociedade quanto à sua necessidade como direito humano. Afinal todos desejam cada vez mais expressar-se e comunicar seus pontos de vista. A democratização da comunicação e dos meios, as formas de acesso, a pluralidade de expressão das culturas, a igualdade para informar-se e ser informado, sem discriminação ou exercício de poder sobre os menos privilegiados economicamente, são condições necessárias à horizontalidade da comunicação na esfera pública no sentido de tornarse um direito social.

Se forem consideradas as relações internacionais, por exemplo, é de direito que a sociedade reconheça os direitos humanos dos cidadãos a partir dos direitos universais do ser humano e que as nações respeitem esses direitos, independentemente do tipo da formação do Estado. Portanto, qualquer informação quanto ao cerceamento desses direitos hoje poderia ser veiculada pela mídia, mesmo contra a vontade de 
terceiros. Nesse aspecto, é a mídia que toma para si o direito de informar aos cidadãos que determinados direitos humanos estariam sendo negados a outros cidadãos. Assim, pode contribuir para a mediação das relações de negociação entre órgãos mundiais de defesa dos direitos humanos e as nações.

O tema dos direitos humanos passou a ter relevância internacional após a Segunda Guerra (1939 a 1945), em razão da forte comoção causada ao mundo pelo sofrimento das vítimas do holocausto. A partir daí, a comunidade internacional preocupa-se visivelmente com qualquer tipo de violação aos direitos humanos, especialmente das minorias. Por isso, os meios de comunicação estão cada vez mais atentos a questões como estas em todos os países do mundo, porque há certa cobrança em relação a estes aspectos. Questões de gênero, a causa das mulheres, o trabalho escravo, a exploração de crianças são alvos de alerta e foco de atenção da mídia, porque constituem crimes contra os direitos humanos e a cidadania universal, direitos internacionalmente assegurados.

A afirmação de Celso Lafer (1991, p. 241) de que "todo o indivíduo tem direito à liberdade de opinião e de expressão, o que implica o direito de não ser inquietado pelas suas opiniões e o de procurar, receber e difundir, sem consideração de fronteiras, informações e ideias por qualquer meio de expressão" vai ao encontro do que se acredita ser o exercício pleno de uma democracia em que os cidadãos têm o direito de manifestar suas opiniões, acerca de questões particulares e públicas, com autonomia e independência, expressando suas vontades e interesses.

De acordo com Victor Gentilli (2005, p. 129), "o direito à informação deve ser pensado na perspectiva 
de um direito para todos" e também, "na perspectiva de fornecer informações em quantidade e qualidade para o melhor julgamento possível de cada um". Sem o exercício do direito à informação, a cidadania sofreria prejuízos, pois os cidadãos não obteriam aquelas informações essenciais no dia a dia, inclusive para cumprir os seus deveres. Ao mesmo tempo em que se deve ter acesso às informações, tem-se o direito à privacidade. O ser humano é, assim, tanto livre para opinar quanto para dar-se o direito de permanecer calado, ou não publicar informações privadas e de sua intimidade. É o princípio da equidade aplicado ao direito de opinião e informação.

Sabe-se também que há um aumento de circulação das informações, de forma mais rápida, porém, mesmo com canais e sistemas tecnológicos mundiais, não há garantia de pluralismo. Segundo Dominique Wolton (2010, p. 67), "nada indica que a aldeia global será uma aldeia de diversidade. Pode ser que a uniformização predomine por força da concentração das indústrias culturais e da comunicação". Os modelos de informação e comunicação existentes não são garantia, portanto, de que a informação de que os cidadãos necessitam, vá realmente circular amplamente. Mas, acredita-se que é preciso "respeitar a pluralidade dos pontos de vista sobre o mundo e a necessidade de um princípio comum" (WOLTON, p. 67). $O$ jornalismo foi no decorrer do tempo e em todos os países um dos elementos mais importantes para "a garantia da liberdade de informação" (WOLTON, p.71). Mas jornalismo não é espetáculo e o público receptor não tem poder de juiz. É coerente "manter acessível aos cidadãos as três escalas de informação constitutivas da nossa relação com o mundo: local, 
nacional e mundial. Sem isso, corre-se o risco de que a desvalorização de uma dessas três referências resulte num profundo desequilíbrio" (WOLTON, 2010, p.76).

A informação torna-se vazia quando não está embasada no conhecimento. Com um grande número de informações circulando de forma acessível, é importante ter os conhecimentos necessários para fazer a interpretação de todo o contexto e das relações que o envolvem. Wolton (2010, p.79) afirma que "a globalização e seus perigos obrigarão a um enquadramento da informação. As ciências e as tecnologias estarão cada vez mais no centro das sociedades e dos debates políticos". Diante disso, os dois meios deverão "aprender a redefinir suas relações com o mundo e entrar em colaboração", conservando o "seu espaço de legitimidade para que o receptor entenda a convivência de pontos de vista diferentes".

Segundo Gentilli (2005, p. 130), tradicionalmente, os estudos acerca da cidadania "não fazem referência ao direito à informação". Este autor defende a posição do acesso à informação como um direitomeio, ou seja, "o direito àquelas informações necessárias e imprescindíveis para a vida numa sociedade de massas, aí incluído o exercício pleno do conjunto de direitos civis, políticos e sociais". A cidadania aqui está vinculada ao papel da mídia de ao mesmo tempo ser mediadora e representante do coletivo de receptores. Sendo assim, a mídia seleciona, filtra e organiza as informações para o público, tendo presente o fato de que ela tem legitimidade para representá -lo, ou seja, precisa fazê-lo dentro da ética, porque representa o receptor no ato de buscar e organizar a informação. 
O direito de informar, de informar-se, de ser informado e o direito às histórias e fatos em profundidade completam o sentido do direito à informação. O compromisso com a apuração e a ética do tratamento das informações é o que dará legitimidade ou confiabilidade à mídia. O que muda hoje, em relação há uma década atrás, é a acessibilidade e as formas de participação dos cidadãos na mídia tradicional, ou nas mídias sociais digitais.

\section{2. $\bigcirc$ jornalismo e suas narrativas}

Ao mesmo tempo em que receptores alcançam também o status de emissores, com as novas tecnologias da comunicação, o lugar do jornalismo se reafirma como o polo hegemônico do dizer, do narrar o que acontece na vida em sociedade. Motta (2013) observa que se aceitarmos que o presente se adensou e se expandiu, cresce a necessidade de analisar a narrativa jornalística "como instituinte e constituinte desse fugidio presente" (MOTTA, 2013, p. 103). E justifica: "Até porque o jornalismo é a narrativa hegemônica sobre todas as outras na construção da verdade imediata e do senso comum" (op. cit.).

Os cidadãos atualmente conectados utilizam as mídias sociais digitais como um novo lugar de dizer, de narrar. Mas, em muitas situações, repercutem ali o que é dito pela imprensa tradicionalmente organizada, avalizando a credibilidade e reputação que esta reivindica, justamente por ter como atividade primordial narrar o que acontece. O jornalismo pode ser explicado, sustenta o português Nelson Traquina, pela frase de que é a resposta à pergunta "o que aconteceu/ está acontecendo?" (TRAQUINA, 2005, p. 19). 
O fato de que o jornalismo segue constituindo-se como narrativa hegemônica sobre as demais, reforça o compromisso que este deve ter ao comunicar, levando-se em conta as discussões acima expostas.

Para Motta (2013, p. 33), que se dedica ao estudo das narrativas, estas não apenas representam a realidade do que aconteceu, mas "apresentam e organizam o mundo, ajudam o homem a construir a realidade humana". A visão de Motta aproxima-se da perspectiva de diversos pesquisadores dos campos da sociologia e do jornalismo que procuram compreender o papel do jornalismo na representação/ apresentação da realidade.

João Carlos Correia (2009, p. 5128), por exemplo, afirma que os jornalistas intervêm ativamente na construção das condições e do modo em que a realidade é percebida. Gaye Tuchman (1983, p. 198) sustenta que a notícia não espelha a sociedade, mas, ajuda a constituí-la como um fenômeno social compartilhado.

Assim consideramos que as narrativas jornalísticas são elementos importantes para a compreensão da realidade. Para isso, compartilhamos do entendimento de Fernando Resende (2009, p 3), para quem o ato de narrar "deriva da premência de se estabelecerem modos de compreensão e entendimento do mundo em que se vive", cujo contar "pode nascer hoje, principalmente, nos vários lugares em que a vida acontece".

Resende afirma que ao considerar-se as narrativas como lugar de produção de conhecimento coloca em evidência o lugar em que se realizam as ações e performances socioculturais. "Assim, pensar, (re)conhecer e analisar as narrativas jornalísticas à luz de sua tessitura pode ser um caminho tanto para se conhecer o jornalismo quanto o seu próprio fazer 
(RESENDE, 2009, p. 35). Até porque, ainda de acordo com o mesmo autor (RESENDE, 2011 , p.121), o jornalismo precisa enfrentar o paradoxo em que está imbricado: "dar a ver o mundo que, na sua totalidade, por meio da linguagem, é inapreensível". É ao narrar que criamos o acontecimento, explica, ao darmos vida aos objetos de que falamos e aos sujeitos a quem nos referimos ou com quem pretendemos falar. Mas, a narrativa, o discurso não é da ordem do real.

Ao propor um método de estudo das narrativas, Motta (2013, p. 106) afirma que as análises são realizadas para compreender como se integram os sentidos fragmentados das notícias do dia a dia, "de que maneira elas transformam, por meio de colaborações ou de enfrentamentos entre os atores sociais envolvidos, em representações unitárias mais ou menos tangíveis (estórias, contos, fábulas, ideologias em ação)". Ao colocar esses atores sociais em enfrentamento, o jornalismo torna os acontecimentos do presente inteligíveis, "faz os incidentes tomarem a forma de sequências, faz as novidades adquirirem significação minimamente coerente e consistente, ainda que relativamente provisória" (MOTTA, 2013, p. 105).

É entendendo essa materialidade do texto jornalístico enquanto narrativa, que se analisa a cobertura sobre direitos humanos nos jornais Folha de S. Paulo e Jornal do Brasil. Entende-se que a produção de textos, feita por jornalistas, aciona determinados temas para debate público. A narrativa sobre os temas só se completa no receptor, que reconstrói as histórias que lê, junta os fragmentos das notícias publicadas em diferentes dias, na lógica do tempo jornalístico que é diferente do tempo da vida e, assim, constrói também suas significações. Para isso, o 
trabalho parte de uma análise de conteúdo sobre direitos humanos nos referidos jornais.

\section{Direitos humanos nas narrativas da Folha de S. Paulo (impresso) e Jornal do Brasil ( on-line)}

Ao analisar as publicações da Folha de S. PauIo' e do Jornal do Brasil on-line ${ }^{2}$, no que diz respeito aos direitos humanos, no período de agosto de 2014 a março de 2015, observou-se como ponto de partida as palavras-chave: direitos humanos; democracia; liberdade de expressão, cidadania; direito à informação, censura ${ }^{3}$, manifestações populares ${ }^{4}$. Essas palavras-chave foram consideradas as unidades de registro para a análise do conteúdo proposta. De acordo com Laurence Bardin (2011), a organização da análise inicia-se com a seleção do material a ser analisado, a partir da formulação de hipóteses da pesquisa. Após a primeira etapa, que inclui a leitura flutuante e a definição dos objetivos, os dados devem ser codificados e agregados em unidades, as "unidades de registro", que permitem a descrição de características pertinentes ao conteúdo analisado. As unidades podem ser palavras, temas, objetos,

\footnotetext{
1 A Folha de S. Paulo, fundada em 1921, é um dos jornais impressos de maior circulação no Brasil, com uma tiragem diária de cerca de 300 mil exemplares. A página da Folha de S. Paulo na internet é http:// www.Folha de S. Paulo.vol.com.br onde a versão impressa pode ser acessada mediante assinatura digital.

2 O Jornal do Brasil on-line é a versão digital do Jornal do Brasil, fundado em 8 de abril de 1891, logo após a Proclamação da República. Em setembro de 2010 o Jornal do Brasil passa a ser veiculado somente na versão digital e pode ser acessado em http://www.jb.com.br, sem necessidade de assinatura.

3 Palavra-chave pesquisada somente no Jornal do Brasil on-line.

4 Palavra-chave pesquisada somente na Folha de S. Paulo.
} 
referentes, ou ainda personagens, acontecimentos, documentos.

Para abranger o período de sete meses, entre agosto de 2014 e março de 2015, foram selecionadas edições dos jornais em dias alternados e no fim de semana, ou seja: terça-feira, quinta-feira, sábado e domingo, seguindo o critério de abrangência semanal, observando quatro das sete edições, número considerado suficiente para os objetivos da pesquisa e para o período total de meses de acompanhamento do objeto. Para chegar-se à composição do corpus, partiu-se de 136 edições de cada um dos jornais.

Metodologicamente a pesquisa partiu da leitura dos jornais nos dias correspondentes ao da pesquisa, selecionando as matérias que continham as unidades de registro definidas na pré-análise. À medida que essa leitura era realizada, verificou-se que muitas das matérias tratavam sobre as questões pesquisadas, mas, não continham as palavras-chave. Como eram relevantes para o corpo da pesquisa, optou-se por analisá-las da mesma forma, selecionando todo o material e arquivando-o em ordem cronológica pelo dia e mês correspondente.

Com relação à Folha de S. Paulo, primeiro foram separados os Cadernos ${ }^{5}$ do corpo do jornal para depois proceder à leitura, começando pelo título, lead, e corpo do texto. Quando encontrada uma matéria com as palavras-chave ou que tinha relação com os direitos humanos, era separada nas seguintes categorias: reportagem; notícia; entrevistas; publicidade; editorial; charges, infográficos e fotos; artigos de

5 São os seguintes os Cadernos da Folha de S. Paulo separados pela pesquisa do corpo do jornal para análise: Mundo, Poder, Cotidiano, Mercado, Ilustrada, Ilustríssima, Esporte, Turismo e Classificados. 
colunistas e opinião do leitor, para serem analisadas quanto ao seu conteúdo e abordagem. Da mesma forma, ocorreu com a pesquisa no Jornal do Brasil, cujo material selecionado foi arquivado em forma de prints nas mesmas categorias.

A Folha de S. Paulo apresenta, no período pesquisado, 1.156 matérias relacionadas à proposta deste estudo. Destas, 341 se enquadram nas unidades de registro e, na maior parte delas (815), o conteúdo para a análise não se encontra presente. As categorias estão assim representadas no conjunto das publicações: 149 reportagens, 504 notícias, 29 entrevistas, 78 editoriais, 28 charges, infográficos e fotos, 147 artigos de colunistas, 217 opiniões de leitores e 4 publicidades. No Jornal do Brasil, nas edições catalogadas são 281 notícias, 41 reportagens, 38 colunas, 41 artigos de opinião e 1 editorial, totalizando 792 matérias sobre a questão abordada. Destas, 736 apresentam as palavras-chave e outras 56 não fazem menção a elas.

Observa-se que, quantitativamente, a Folha de S. Paulo publicou no mesmo período um número maior de matérias relativas à questão pesquisada comparando com o Jornal do Brasil on-line. Porém, o número de matérias com as palavras-chave no Jornal do Brasil on-line é superior à Folha de S. Paulo. Entre os assuntos que foram abordados pela Folha de S. Paulo incluídos na perspectiva da pesquisa estão matérias de cunho político, relacionadas à cidadania e ao direito ao voto. Posiciona-se favoravelmente a questões como aborto, legalização das drogas, casamento homoafetivo e coloca-se contrária à maioridade penal e pena de morte. Durante o período, a Folha de S. Paulo veiculou matérias sobre xenofobia, racismo, conflitos 
religiosos no Oriente Médio, eleições, discriminação de gênero, bem como tratou sobre temas específicos como o atentado ao Charlie Hebdo, a finalização do relatório da Comissão Nacional da Verdade ou sobre as declarações do Vaticano em favor dos gays. O editorial da Folha de S. Paulo publicou também textos sobre liberdade de expressão e direito à informação, condenando uma proposta do Senado de proibir pesquisas de intenção de voto antes das eleições.

Observa-se que as pautas seguem naturalmente a agenda do contexto social e político, a partir de onde se apresenta no contexto da sociedade, não havendo uma provocação do jornal para fazer um agendamento próprio de questões relacionadas ao foco da pesquisa. Ou seja, o jornalismo da Folha de S. Paulo aborda os direitos humanos de maneira episódica, a partir de pautas que emergem como acontecimento, que o jornalismo se propõe a narrar. Não tematiza, necessariamente, os direitos humanos. Reges Schwaab; Frederico Tavares (2009, p. 181) abordam o tema e explicam que "no jornalismo das hard news, o tema só emerge de forma explícita, como uma pauta específica, encaixando-se nas lógicas da temporalidade jornalística e dos valores-notícia, ou seja, 'concorrendo' com o acontecimento".

Pelo que apontam os dados da pesquisa realizada com a Folha de S. Paulo, o jornal se preocupa com a questão dos direitos humanos, mas, de forma singular, a partir de casos isolados, sem associá-los ao contexto ou aprofundar a questão. Constata-se que menos de $30 \%$ das publicações trazem as palavraschave selecionadas, o que diminui praticamente a visibilidade pelo leitor quanto à abordagem. Ou seja, por não se deparar explicitamente com as palavras- 
chave de forma visível no título, no lead ou no texto, o leitor terá que perceber sozinho que o jornal está falando sobre direitos humanos em dado momento, reconhecendo, por exemplo, que temas como homofobia, racismo, escravidão, tortura, liberdade religiosa, discutidos pela Folha de S. Paulo, dizem respeito aos direitos humanos e que o jornal teria intenção de discutir isso. Conforme afirma Rogério Christofoletti (2002, p. 262), "o leitor pode exercer sua cidadania diante das próprias páginas do jornal que tem nas mãos. Sua leitura precisa ser atenta e contextualizadora", afirma, explicando que "basta", para isso, uma "certa dose de senso crítico, aliada a alguma memória, e abastecida continuamente com novas informações".

Por essa razão, não se descarta o papel formador de opinião e difusor de cultura da Folha de S. Paulo. Observa-se que o jornal abre espaço para pensamentos de diferentes orientações, publica opiniões adversas às do conteúdo de algumas matérias na coluna Painel do Leitor e na coluna do Ombudsman, estrategicamente pensada para refletir sobre pontos de vista do veículo em relação aos temas abordados. Como a Folha de S. Paulo goza do prestígio de ser um jornal de referênciab ${ }^{6}$, autoriza-se a publicar essas opiniões, sem risco de perder sua credibilidade junto aos leitores. Ao contrário, isso Ihe dá crédito porque sinaliza um espaço de diálogo com o seu público, mesmo aquele que não concorda com elas.

No que diz respeito ao Jornal do Brasil, a metodologia utilizada para seleção do material se deu de forma semelhante à da Folha de S. Paulo. O que muda é o modo de registrar os dados coletados, que

6 "Jornal de referência" pode ser entendido como um jornal que é referência para demais veículos de comunicação (ZAMIN, 2014). 
foram arquivados digitalmente, a partir de um prints das matérias.

Entre todas as palavras-chave, direitos humanos é a palavra encontrada de modo mais frequente no Jornal do Brasil on-line e relaciona-se, quase sempre, a questões que dizem respeito ao quotidiano do Rio de Janeiro, com matérias sobre segurança pública e violência, reforçando a designação da imagem do Rio de Janeiro como violenta.

Chamam atenção também os números associados à palavra-chave democracia, especialmente nos meses de agosto (44), setembro (43) e, principalmente, outubro (63). Atribui-se à incidência elevada desta palavra-chave nesse período, em grande parte às eleições, realizadas em outubro de 2014, e aos fatos relacionados às campanhas políticas que as antecederam, o que demonstra uma preocupação do jornal com temas oriundos da agenda política e que dizem respeito ao exercício da cidadania.

No Jornal do Brasil on-line há uma maior concentração das menções aos assuntos das palavraschave na categoria notícias. O jornal prioriza uma abordagem rápida para suas pautas, e as notícias são o gênero mais frequente no jornalismo do Jornal do Brasil, não apenas quando o assunto é direitos humanos. A categoria notícia, portanto, representa o formato de texto predominante entre as postagens do Jornal do Brasil.

Quanto ao jornalismo de caráter opinativo o Jornal do Brasil on-line destaca-se quanto ao número de colunas (38), e opinião do leitor (41) e deixa a desejar nos editoriais (1). Observa-se que os colunistas habituais e a seção chamada "Comunidade em pauta" abordam, frequentemente, os fatos noticiados 
pelo jornal através de uma perspectiva preocupada com a defesa dos direitos humanos e da democracia, o que é relevante quanto àquilo que se espera do jornalismo como produtor de sentidos. O Jornal do Brasil on-line prioriza os direitos humanos a partir das pautas de democracia, o que está extremamente relacionado, no período de realização da pesquisa, às eleições de 2014 no Brasil, à segurança pública e, pautas internacionais ligadas a direitos.

A leitura e análise dos dados reforçam o potencial de geração de sentidos do jornalismo:

...menos que determinar sobre o que pensar, os meios de comunicação são vistos como aqueles que ofertam sentidos sobre alguma questão, participando de um circuito no qual o público também é visto como agente produtor de significados. Assim, os sentidos veiculados pela mídia, apesar de escaparem do seu controle, reforçam a capacidade que certas temáticas têm de operar processos de circulação significante na relação mídia e sociedade. (SCHWAAB; TAVARES, 2009, p. 183).

Avaliamos, portanto, que, do ponto de vista jornalístico - e considerando o direito à informação como um requisito para o exercício da cidadania -, a Folha de S. Paulo e o Jornal do Brasil on-line podem contribuir de forma mais direta para a promoção da cultura dos direitos humanos:

a) Fazendo uma abordagem mais específica e aprofundada dos assuntos sobre direitos humanos nas matérias publicadas, tematizando os direitos humanos;

b) Qualificando as matérias que abordam os direitos humanos no contexto brasileiro; 
c) Utilizando de forma mais frequente a denominação direitos humanos em manchetes/ títulos, leads e no corpo do texto.

Uma abordagem mais específica dos assuntos relacionados aos direitos humanos e uma discussão mais aprofundada fazem-se necessárias pelo papel que se espera dos meios de comunicação. Abordar os direitos humanos como tema, não apenas a partir da cobertura episódica de fatos que envolvem direitos humanos, pode contribuir para aprofundar o debate sobre o tema na sociedade, já que o jornalismo produz sentidos e faz circular saberes.

Percebe-se que a Folha de S. Paulo dedica um número considerável de matérias aos direitos humanos. Porém, observa-se que a abordagem dá mais atenção às pautas internacionais que envolvem o tema. Não que estas devam ser desconsideradas, mas abordar as questões dos direitos que afetam a realidade brasileira poderia contribuir para pautar os direitos humanos no contexto do país. O Jornal do Brasil on-line apresenta produção jornalística mais freqüente, envolvendo o tema no Brasil, mas, reforça uma narrativa especialmente sobre o Rio de Janeiro como cidade violenta. Ao tematizar os direitos humanos, ambos os jornais poderiam contribuir para um debate mais profundo, sintonizado com o que acontece no território brasileiro, sem perder de vista as orientações contemporâneas do direito internacional.

Entende-se ainda que por mais simples que pareça, a palavra concreta - direitos humanos - estampada num título, lead ou texto dá maior visibilidade ao tema, contribuindo para que o público perceba mais facilmente a preocupação dos jornais em debater a questão. Essa marca oferece uma direção ao leitor. 
A palavra dita, narrada, tem potência, gera significados. "Os fatos não falam por si e é na narração que, a partir de um jogo de forças, o compartilhamento é (e não é) potencializado, ao mesmo tempo em que é (ou não) viabilizado o propósito da comunicação" (RESENDE, 2011, p. 127).

\section{Considerações finais}

No estudo da narrativa jornalística, Motta (2013) aponta três instâncias de análise: o plano da expressão, que podemos entender como a linguagem, ou discurso, o plano da estória ${ }^{7}$, que se trata do conteúdo, da intriga desenrolada pela narrativa e o plano da metanarrativa, entendido como o plano de fundo sobre o qual se desenvolve a história da narrativa em questão. Embora a proposta desse artigo não seja fazer necessariamente uma análise da narrativa, lançamos um olhar narrativizante, na esteira de Bruno Leal (2013) ao conteúdo analisado da produção jornalística sobre direitos humanos. E percebemos, a partir das unidades de registro para a análise, e da leitura do plano de expressão da narrativa que, ainda que não sejam nomeadas como direitos humanos, as pautas estão nas páginas dos jornais. Surgem, a partir das metanarrativas contemporâneas: quando o cenário é eleitoral, questões como liberdade de expressão, direito a informação, censura, são acionadas. Homofobia, aborto, racismo, escravidão, liberdade religiosa, são temas que aparecem nas páginas dos jornais, repercutindo situações da vida cotidiana, dramas individuais com potenciais coletivos (quando se entende que o desrespeito de direitos de uma pessoa,

\footnotetext{
$7 \quad$ Aqui se utiliza a grafia adotada pelo próprio autor para nomear a instância de análise.
} 
ameaça os direitos da coletividade), e constituem a agenda comum do que o jornalismo compreende que se precisa saber e, então elege estes fatos, entre tantos outros que não chegam às páginas dos jornais, como fundamentais ao conhecimento dos cidadãos.

Todos esses fragmentos, essas notícias que abordam desde liberdade de expressão, a aborto, cidadania, manifestações populares, ainda que lidas em separado, vão conformando o mosaico a partir do qual os leitores, receptores dessas informações as interpretam, as somam ao seu repertório para a leitura do mundo. Motta (2013, p. 101) cita o pesquisador catalão Albert Chillón quando aborda a tematização, que define como o "processo cognitivo de juntar fragmentos em um só tema". Esse processo, para o autor, possibilitaria aos indivíduos a capacidade de transformar partes desordenadas dos conteúdos dos meios de comunicação em núcleos temáticos básicos. Assim, pelas notícias fragmentadas de diferentes temas que circunvizinham os direitos humanos, temos a constituição de um tema, o tema dos direitos humanos na narrativa dos jornais.

Essa abordagem e essa narrativa, contudo, podem ser mais exploradas se tratadas pelos jornais com aprofundamento e contextualização, como temas centrais. Schwaab; Tavares (2009, p. 186) buscam diálogo com o jornalismo na noção de tema gerador de Paulo Freire (2005) e concluem que é possível pensar na "capacidade temática de falar sobre certos assuntos da e na sociedade, conferindo a eles não apenas um lado conteudístico, mas, também, dinamizador de certas operações e significados, que permita observar a realidade de outras formas e dela participando". 
Compreendemos os direitos humanos como um tema fundamental na cena política internacional. Portanto, cabe à mídia atribuir o mesmo tratamento aos direitos humanos que dá a outras pautas de igual natureza. Os direitos humanos não são mais importantes que outros temas, porém, requerem ainda uma maior atenção da mídia no quesito apuração e contextualização. O papel dos meios de comunicação, dentro de uma perspectiva de informação voltada para o interesse público, passa pelo compromisso de propiciar, a partir das narrativas jornalísticas, a difusão das discussões em torno desse tema, considerando a informação como condição para que os cidadãos possam usufruir da informação como direito-meio (GENTILLI, 2005) para acessar outros direitos.

Dessa forma, pelas narrativas jornalísticas o cidadão estaria provido de elementos para melhor compreender os direitos humanos na atualidade, como imprescindíveis para a vida em sociedade. Os jornais analisados, ainda que acionem fatos, histórias e informações ligadas aos direitos humanos em suas narrativas, não os tematizam, o que aponta para a fragilidade do conhecimento sobre o assunto. Com maior precisão, conhecimento e apuração do tema, o jornalismo estaria contribuindo de modo mais evidente para a cidadania e a formação de uma cultura dos direitos humanos.

\section{Referências}

BARALDI, Camila Bibiana Freitas. Migraçoes internacionais, direitos humanos e cidadania sul-americana. 151 p. Tese de Doutorado Universidade de São Paulo, São Paulo, 2014.

BARDIN, Laurence. Análise de conteúdo. São Paulo: Edições 70, 2011. BOBBIO, Norberto. O futuro da democracia: uma defesa das regras do jogo. Rio de Janeiro: Paz e Terra, 1986. 
A era dos direitos. Rio de Janeiro: Campus, 1992.

CHRISTOFOLETTI, Rogério. Do leitor imperfeito ao cidadão mais-que-perfeito: um ano do sítio Monitor de Mídia. In: HOHLFELDT, Antonio; BARBOSA, Marialva (Orgs.). Jornalismo no século XXI: a cidadania. Porto Alegre: Mercado Aberto, 2002.

CORREIA, João Carlos. Elementos para uma abordagem sociofenomenológica da teoria da notícia. In: VI SOPCOM - Congresso da Associação Portuguesa de Ciências da Comunicação, 2009, Lisboa. Anais do VI SOPCOM, VIII LUSOCOM. Lisboa: SOPCOM - Universidade Lusófona de Lisboa, 2009. v. 1. p. 5127 - 5142.

FREIRE, Paulo. Pedagogia do oprimido. Rio de Janeiro: Paz e Terra, 2005.

GENTILLI, Victor. Democracia de massas: jornalismo e cidadania: estudo sobre as sociedades contemporâneas e o direito dos cidadãos à informação. Porto Alegre: EDIPUCRS, 2005.

LAFER, Celso. A reconstrução dos direitos humanos. Rio de Janeiro: Cia das Letras, 1991.

LEAL, Bruno Souza. O jornalismo à luz das narrativas: deslocamentos. In: LEAL, Bruno Souza; CARVALHO, Carlos Alberto de (Orgs.). Narrativas e poéticas midiáticas: estudos e perspectivas. São Paulo: Intermeios, 2013.

MOTTA, Luiz Gonzaga. Análise crítica da narrativa. Brasília: Editora Universidade de Brasília, 2013.

PERUZZO, Cicília. Sociedade da Informação no Brasil: desafio de tornar a Internet de todos para todos. In: PERUZZO, Cicília; BRITTES, Juçara. Sociedade da informação e novas mídias: participação ou exclusão? Coleção Intercom de Comunicação, n. 14. São Paulo: Intercom, 2002.

RADDATZ, Vera Lucia Spacil. Direito à informação como exercício da cidadania. Revista Direitos Culturais, v.9, n.19, p. 108-117, 2014.

RESENDE, Fernando. Às desordens e aos sentidos: a narrativa como problema de pesquisa. In: SILVA, Gisele et al. (Orgs.). Jornalismo contemporâneo: figurações, impasses e perspectivas. Salvador: EDUFBA; Brasília: Compós, 2011. 
O jornalismo e suas narrativas: as brechas do discurso e as possibilidades do encontro. Revista Galáxia, n. 18, p.31-43, dez. 2009. Disponível em: <http://revistas.pucsp.br/index.php/galaxia/article/ viewFile/2629/1671> Acesso em: 20 maio 2015.

SCHWAAB, Reges Toni; TAVARES, Frederico de Mello Brandão. O tema como operador de sentidos no jornalismo de revista. Revista Galáxia, n. 18, p.180-193, dez. 2009.

TRAQUINA, Nelson. Teorias do jornalismo: porque as notícias são como são. v. 1. 2. ed. Florianópolis: Insular, 2005.

TUCHMAN, Gaye. La producción de la noticia: estudio sobre la construcción de la realidade. Barcelona: Editorial Gustavo Gili, 1983.

WOLTON, Dominique. Informar não é comunicar. Porto Alegre: Sulina, 2010.

ZAMIN, Angela. Jornalismo de referência: o conceito por trás da expressão. In: Revista FAMECOS, Porto Alegre, v. 21, n. 3, p. 918-942, set.-dez. 2014.

\section{Vera Lucia Spacil Raddatz}

Doutora em Comunicação pela Universidade Federal do Rio Grande do Sul

Docente do Programa de Pós Graduação em Direito - Mestrado em Direitos Humanos - e do Curso de Jornalismo, da UNIJUI.

Lattes: http://lattes.cnpq.br/1381583047595764

\section{Lara Nasi}

Doutoranda em Comunicação pela Universidade Federal de Santa Maria

Docente no curso de Jornalismo da Universidade Regional do Noroeste do Rio Grande do Sul.

Lattes: http://lattes.cnpq.br/0784414112975111 